\title{
Mucosal flora of the small intestine and the effect of preoperative antibiotics
}

\author{
MARGARET E ELMES,${ }^{*}$ CHL HOWELLS,$\dagger$ GH LOWE $\dagger$ \\ From the *Department of Pathology and †Public Health Laboratory Service, University Hospital of Wales, \\ Cardiff
}

SUMMARY Samples of mucosa from the small intestines of 100 patients undergoing intestinal surgery were examined bacteriologically. Sixty four patients had received chemotherapy, 12 for more than $24 \mathrm{~h}$ before operation. Most of the jejunal samples were sterile unless there was a carcinoma, previous surgery, or potential intestinal stasis. Ileal mucosa was more likely to contain intestinal organisms. Most of the strains isolated were sensitive in vitro to the antibiotics given in vivo, but short term treatment may not have allowed sufficient time for the treatment to have become effective. The findings suggest that antibiotics are not needed for most operations on the duodenum or jejunum but may be required for operations on the ileum.

Previous investigations of the bacterial flora of the small intestine have usually involved examination of the luminal contents. ${ }^{1-3}$ In this series we have cultured samples of intestinal mucosa obtained at surgical resection to identify any micro-organisms present and to observe the effect of preoperative chemotherapy.

\section{Material and methods}

One hundred patients undergoing intestinal resection at this hospital were studied over a five year period. Ethical approval was obtained for the collection of specimens. There were 44 males and 56 females, whose ages ranged from one month to 85 years (mean $55 \cdot 8 \pm 18 \cdot 5$ ). In the cases involving the duodenum and jejunum the conditions requiring surgery were peptic ulcer, carcinoma of the oesophagus, stomach, and pancreas, and lymphoma of the stomach; in the ileum, Meckel's diverticulum, angiodysplasia, polyposis coli, carcinoma of the caecum or colon, and Crohn's disease were the reasons for operation.

\section{ANTIBIOTICS ADMINISTERED}

Preoperative administration of antibiotics was either short term (less than $24 \mathrm{~h}$ before operation) or long term (more than $24 \mathrm{~h}$ preoperatively). All antibiotics given were in standard adult or paediatric doses. Most of the short term chemotherapy was given either with premedication or induction of anaes- thesia. Long term antibiotics were given for preexisting infections or when there had been an operative procedure within a week.

COLLECTION AND TRANSPORT OF SPECIMENS Fresh mucosal samples were collected from the operating theatre in sterile plastic bags, transferred to sterile Petri dishes, and divided into suitable sized pieces with a sterile knife for histological studies. ${ }^{4}$ The remainder was put into preweighed bijou bottles, containing $5 \mathrm{ml}$ glycerol transport broth. ${ }^{5}$ On arrival at the laboratory they were refrigerated before examination. Most specimens were examined within $1 \mathrm{~h}$ of receipt or stored at $-20^{\circ} \mathrm{C}$.

\section{BACTERIOLOGICAL EXAMINATION}

After being weighed, each sample was agitated by swirling in transport medium at low speed for $3 \mathrm{~min}$ using a homogeniser. The supernatant was removed, replaced with $5 \mathrm{ml}$ of sterile quarter strength Ringer's solution, and the agitation repeated. The remaining washed tissue was then transferred to a sterile Griffith tube containing $5 \mathrm{ml}$ quarter strength Ringer's solution and well macerated. The supernatant fluid was removed after allowing tissue fragments to settle.

The two samples of washings and the macerated supernatant were diluted with quarter strength Ringer's solution using a double dilution method from neat to $1 / 64$. Nutrient blood agar and MacConkey agar plates were inoculated and incubated aerobically at $37^{\circ} \mathrm{C}$ for $24 \mathrm{~h}$. Plates containing 
Table 1 Identities of organisms isolated

\begin{tabular}{lr}
\hline -haemolytic streptococci & 25 \\
Streptococcus viridans (not further identified) & 15 \\
Str mitis & 1 \\
Str sanguis & 4 \\
Str bovis & 1 \\
Str milleri & 1 \\
Str mitior & 1 \\
Str salivaris & 2 \\
Str faecalis & 5 \\
Enterobacteriaceae & 41 \\
Escherichia coli & 25 \\
Coliform bacteria (not further identified) & 2 \\
Enterobacter cloacae & 2 \\
Ent agglomerans & 1 \\
Ent hafnia & 1 \\
Proteus morgani & 3 \\
Pr mirabilis & 1 \\
Klebsiella spp & 4 \\
Serratia rubrica & 1 \\
Pseudomonas spp & 1 \\
Anaerobes & 9 \\
Clostridium perfringens & 3 \\
Bacteroides & 4 \\
Bact corrodens & 1 \\
Gram positive bacillus (not further identified) & 1 \\
Others & \\
Coagulase negative staphylococcus & \\
Micrococcus tetragenus & \\
$\beta$ Lactobacillus sp & 1 \\
Haemophilus infuenzae & 1 \\
Total & 1 \\
\hline
\end{tabular}

$20 \mu \mathrm{g} / \mathrm{ml}$ neomycin sulphate were used for anaerobic culture. All isolates were identified by standard methods and surface counts at the various dilutions were performed. ${ }^{6}$ The anaerobic plates were examined after $48 \mathrm{~h}$ incubation. The colony counts were multiplied by the appropriate dilution factor and expressed as total numbers of bacteria per gram of tissue. Hereafter, the word "sterile" will be used to describe samples that yielded no micro-organisms on culture.

\section{ANTIBIOTIC SENSITIVITY TEST}

Suitable suspensions of pure cultures of organisms to be tested were prepared in nutrient broth. Nutrient agar lysed horse blood plates were flooded with the suspensions and dried at $37^{\circ} \mathrm{C}$. Oxoid sensitivity multidiscs were placed on to the surface of the dried plates and incubated at $37^{\circ} \mathrm{C}$ for $24 \mathrm{~h}$.

The Oxford Staphylococcus aureus (NCTC6571) and Escherichia Coli (NCTC10418) were used as control organisms.

\section{Results}

One hundred specimens of intestinal mucosa were cultured, three from the duodenum, 53 from the jejunum, and 44 from the ileum. Sixty four patients received antibiotics and 36 did not. The mean colony count increased from 338844 in the jejunum to 512861 in the ileum. These counts could not be correlated with the clinical diagnosis. The identities of the various organisms isolated are shown in Table 1.

\section{DUODENUM AND JEJUNUM}

Twenty eight patients did not receive antibiotics. Nevertheless, twenty two of these produced sterile specimens. Micro-organisms cultured from the other six included $\alpha$-haemolytic streptococci and Haemophilus infuenzae (presumably swallowed). Three produced strains of enterobacteriaceae (Table 2). Only three patients received long courses of antibiotics (Table 3). All of them produced sterile mucosal specimens. Twenty five patients were given

Table 2 Culture of mucosal samples from patients not receiving antibiotics

\begin{tabular}{|c|c|c|c|c|c|c|c|c|}
\hline \multirow[b]{2}{*}{ Site sampled } & \multirow[b]{2}{*}{ No } & \multicolumn{2}{|l|}{ Culture } & \multicolumn{5}{|c|}{ Strains of micro-organisms isolated } \\
\hline & & Sterile & Non-sterile & $\alpha$-haemolytic streptococci & Str faecalis & Enterobacteriaceae & Anaerobes & Others \\
\hline Duodenum & 2 & 2 & 0 & 0 & 0 & 0 & 0 & 0 \\
\hline Jejunum & 26 & 20 & 6 & 6 & 0 & 3 & 0 & 1 \\
\hline Ileum & 8 & 4 & 4 & 1 & 2 & 6 & 0 & 1 \\
\hline
\end{tabular}

Table 3 Duration of antibiotic administration

\begin{tabular}{|c|c|c|c|c|c|}
\hline \multirow[t]{2}{*}{ Site sampled } & \multicolumn{2}{|c|}{$\begin{array}{l}\text { No of patients yielding sterile } \\
\text { specimens }\end{array}$} & \multicolumn{2}{|c|}{$\begin{array}{l}\text { No of patients yielding positive } \\
\text { cultures }\end{array}$} & \multirow[t]{2}{*}{ Total } \\
\hline & Short course & Long course & Short course & Long course & \\
\hline $\begin{array}{l}\text { Duodenum } \\
\text { Jejunum } \\
\text { Ileum } \\
\text { Total }\end{array}$ & $\begin{array}{r}1 \\
16 \\
12 \\
29 \\
\end{array}$ & $\begin{array}{l}0 \\
3 \\
4 \\
7 \\
\end{array}$ & $\begin{array}{r}0 \\
8 \\
15 \\
23 \\
\end{array}$ & $\begin{array}{l}0 \\
0 \\
5 \\
5 \\
\end{array}$ & $\begin{array}{r}1 \\
27 \\
36\end{array}$ \\
\hline Total & \multicolumn{2}{|c|}{36} & \multicolumn{2}{|c|}{28} & 64 \\
\hline
\end{tabular}


Table 4 Type of antibiotic regimen

\begin{tabular}{|c|c|c|c|c|c|c|c|c|c|c|c|}
\hline \multirow[b]{2}{*}{ Site sampled } & \multicolumn{5}{|c|}{$\begin{array}{l}\text { No of patients yielding sterile } \\
\text { specimens }\end{array}$} & \multicolumn{6}{|c|}{$\begin{array}{l}\text { No of patients yielding postitive } \\
\text { cultures }\end{array}$} \\
\hline & Regimen & $\boldsymbol{A}$ & $B$ & $C$ & $D$ & Regimen & $A$ & $B$ & $C$ & $D$ & Total \\
\hline $\begin{array}{l}\text { Duodenum } \\
\text { Jejunum } \\
\text { Ileum } \\
\text { Total }\end{array}$ & & $\begin{array}{l}3 \\
5 \\
8\end{array}$ & $\begin{array}{r}6 \\
7 \\
13\end{array}$ & $\begin{array}{l}1 \\
8 \\
0 \\
9\end{array}$ & $\begin{array}{l}2 \\
4 \\
6\end{array}$ & & $\begin{array}{r}2 \\
10 \\
12\end{array}$ & $\begin{array}{l}1 \\
8 \\
9\end{array}$ & $\begin{array}{l}4 \\
1 \\
5\end{array}$ & $\begin{array}{l}1 \\
1 \\
2\end{array}$ & $\begin{array}{r}1 \\
27 \\
36 \\
64\end{array}$ \\
\hline
\end{tabular}

$\mathrm{A}=$ tobramycin and metronidazole; $\mathrm{B}=\mathrm{a}$ cephalosporin and metronidazole; $\mathrm{C}=\mathrm{a}$ cephalosporin alone; $\mathrm{D}=$ other combinations.

Table 5 Culture of mucosal samples from patients receiving antibiotics

\begin{tabular}{|c|c|c|c|c|c|c|c|c|}
\hline \multirow[b]{2}{*}{ Site sampled } & \multirow[b]{2}{*}{ No } & \multicolumn{2}{|l|}{ Culture } & \multicolumn{5}{|c|}{ Strains of micro-organisms isolated } \\
\hline & & Sterile & Non sterile & $\alpha$ haemolytic streptococci & Str faecalis & Enterobacteriaceae & Anaerobes & Others \\
\hline $\begin{array}{l}\text { Duodenum } \\
\text { Jejunum } \\
\text { Ileum }\end{array}$ & $\begin{array}{r}1 \\
27 \\
36\end{array}$ & $\begin{array}{r}1 \\
19 \\
16\end{array}$ & $\begin{array}{r}0 \\
8 \\
20\end{array}$ & $\begin{array}{l}0 \\
9 \\
9\end{array}$ & $\begin{array}{l}0 \\
1 \\
2\end{array}$ & $\begin{array}{r}0 \\
6 \\
26\end{array}$ & $\begin{array}{l}0 \\
2 \\
7\end{array}$ & $\begin{array}{l}0 \\
1 \\
3\end{array}$ \\
\hline
\end{tabular}

shorter antibiotic courses. A cephalosporin with metronidazole were most frequently used (Table 4). Seventeen of these yielded sterile cultures. Seven of the remaining eight patients produced intestinal micro-organisms, six enterobacteriaceae, and one Clostridium spp with Str faecalis (Table 5). Although $80 \%$ of the strains isolated were sensitive in vitro to the antibiotics given to the patients, short term treatment may not have allowed sufficient time for effective in vivo action. It is of interest that 10 patients produced cultures of intestinal organisms. Antibiotics had been given to seven of them. These patients comprised five with carcinomas, two with peptic ulcers requiring a second operation, and one with Crohn's disease.

It is apparent that the duodenal and jejunal mucosa is usually sterile unless there is disturbance of intestinal flow or carcinoma. Under these circumstances intestinal organisms may be present.

\section{ILEUM}

Only eight of the patients from whom ileal mucosa was obtained had not received preoperative antibiotics. Four produced sterile specimens. The other four yielded two strains of Str faecalis and six strains of various enterbacteriaceae. (Table 2).

Thirty six patients received antibiotics: nine long courses and 27 short courses. Metronidazole with either tobramycin or cephalosporin were prescribed most frequently (Tables 3 and 4). Sterile specimens were obtained from four of those receiving long courses and 12 of those having short term treatment. However, 20 patients produced 26 strains of enterobacteriaceae, nine strains of haemolytic streptococci, two strains of Str faecalis, and seven anaerobes (Table 5). Over $70 \%$ of the isolates were sensitive in vitro to the antibiotics which had been given to the patients. Again, the short course may not have allowed enough time for the treatment to become effective.

Thus the ileal mucosa may contain potentially pathogenic micro-organisms which may persist despite the use of antibiotics.

\section{Discussion}

Although bacteria in the mucosa of the small intestine represent a possible source of perioperative infection, the need for antibiotic cover during operations in this region is still open to discussion.

Most previous studies on the intestinal flora have been done on the large intestine ${ }^{7}$ and on the luminal contents. $^{129}$ Antibiotics are often given in an attempt to prevent infection in this region. The presence of a microbial flora associated with the mucous layer adherent to the washed jejunal mucosa was shown by Plaut et al ${ }^{10}$ and Nelson and Mata." Colonisation of the jejunal mucosa was shown to be an important factor in the pathogenesis of acute tropical sprue, ${ }^{12}$ and the adhesion of bacteria to the mucosa is a factor in pathogenicity. ${ }^{13}$

The relevance of these findings to preoperative bowel "sterilisation" is as yet unclear. It seems likely that bacteria intimately associated with the mucous membrane of the intestinal wall are more important in the pathogenesis of postoperative sepsis than those in the lumen, but to our knowledge this has not yet been shown conclusively.

In our series the duodenal and jejunal mucosae were usually sterile or contained non-pathogenic organisms, even when patients had not received antibiotics. This finding is similar to those of Cregan and Hayward, ${ }^{14}$ who stated that the jejunum and upper ileum were "practically sterile." Again, 
Drasar et $a^{2}$ reported that the upper small intestine was virtually sterile except after a meal, while Barber and Franklin ${ }^{15}$ found that swabs taken from the duodenum were sterile unless a gastric ulcer or carcinoma was present. Nelson and Mata" ${ }^{\text {" }}$ cultured intestinal mucosa and found that non-diseased duodenal mucosa was sterile. Four of seven apparently healthy samples of jejunum contained bacteria in concentrations of $10^{4}$ to $10^{6}$ per gram of tissue, which is similar to our results. When coliforms are present they seem to be associated with "chronic debilitated states. ${ }^{1617}$ We found an association between the presence of intestinal organisms and such states, particularly when there was disturbance of intestinal flow. Thus five patients had carcinoma, two chronic ulcers, and one Crohn's disease. In the ileum, of course, more mucosal specimens containing intestinal organisms were obtained. This again has been recognised by others. ${ }^{71416}$

Our findings suggest that antibiotics are not required for most operations on the duodenum or jejunum unless there is obstruction, a carcinoma, or indications for antibiotics elsewhere in the body. On the other hand, for operations on the ileum there well may be a need for antibiotic treatment as potentially pathogenic "intestinal" organisms may be expected and the chances of local sepsis and passive bacteraemia are increased by possible spillage. These observations agree with those of Keighley, ${ }^{18}$ who stated that "only a few high risk patients need perioperative antibiotics." The organisms are not necessarily eliminated by some of the regimens employed.

\section{References}

' Bishop RF, Anderson CM. The bacterial flora of the stomach and small intestine in children with intestinal obstruction. Arch Dis Child 1960;35:487-91.
${ }^{2}$ Drasar BS, Shiner M, McLeod GM. Studies on the intestinal flora I. Gastroenterology 1969;56:71-9.

${ }^{3}$ Drasar BS, Shiner M. Studies on the intestinal flora II. Gut 1969; 10:812-9.

${ }^{4}$ Elmes ME, Gwyn Jones J, Stanton MR. Changes in the Paneth cell population of human small intestine assessed by image analysis of the secretory granule area. J Clin Pathol 1983;36:867-72.

${ }^{5}$ Crowther JS. Transport and storage of faeces for bacteriological examination. J Appl Bacteriol 1971;34:477-83.

- Miles AA, Misra SS. The estimation of the bactericidal power of the blood. J Hyg Lond 1938;38:732-39.

' Peach S, Lock MR, Katz D, Todd IP, Tabaqchali S. Mucosal associated bacterial flora of the intestine in patients with Crohn's disease and in a control group. Gut 1978;19:1034-42.

${ }^{8}$ Vargo D, Maskovitz M, Floch MH. Faecal bacterial flora in cancer of the colon. Gut 1980;21:701-5.

'Hamilton I, Worsley BW, Cobden I, Cooke EM, Shoesmith JG, Axon ATR. Simultaneous culture of saliva and jejunal aspirate in the investigation of small bowel bacterial overgrowth. Gut 1982;23:847-53.

${ }^{10}$ Plaut AG, Gorbach SL, Nahas L, Weinstein L, Spanknebel G, Levitan R. Studies of intestinal microflora III. The microbial flora of human small intestinal mucosa and fluids. Gastroenterology 1967; 53:838-73.

"Nelson DP, Mata LJ. Bacterial flora associated with the human gastrointestinal mucosa. Gastroenterology 1970;58:56-61.

12 Tomkins AM, Drasar DS, James WPT. Bacterial colonisation of jejunal mucosa in acute tropical sprue. Lancet 1975;i:59-62.

${ }^{13}$ Formal SB, Hale TL, Boedecker EC. Interactions of enteric pathogens and the intestinal mucosa. Phil Trans $R$ Soc (Lond) 1983;303:65-73.

${ }^{14}$ Cregan J, Hayward NJ. The bacterial content of the healthv human small intestine. Br Med J 1953;i:1356-9.

is Barber M, Franklin RH. Bacteriology of stomach and duodenum in cases of peptic ulcer and gastric carcinoma. $\mathrm{Br} \mathrm{Med} J$ 1946; i: 951-3.

${ }^{16}$ Haenal H, Muller-Buethow W. Untersuchungen post mortem uber die Besiedlung des menschlichen Darmkanals. Zbl Bakt 1958; 172: 93-110.

17 Haenel H. Some rules in the ecology of the intestinal microfiora of man. J Appl Bacteriol 1961;24:242-51.

18 Keighley MRB. Perioperative antibiotics. Br Med J 1983;286: 1844-46.

Requests for reprints to: Dr Margaret E Elmes, Department of Pathology, University Hospital of Wales, Heath Park, Cardiff CF4 4XN, Wales. 